\title{
Zeolite Clinoptilolite: Therapeutic Virtues of an Ancient Mineral
}

\author{
Andrea Mastinu ${ }^{1, *,+}{ }^{(}$, Amit Kumar ${ }^{2,+}$, Giuseppina Maccarinelli ${ }^{1}$, Sara Anna Bonini ${ }^{1}{ }^{(\mathbb{D}}$, \\ Marika Premoli ${ }^{1}\left(\right.$, Francesca Aria ${ }^{1}\left(\mathbb{D}\right.$, Alessandra Gianoncelli ${ }^{1}$ and Maurizio Memo ${ }^{1}$ \\ 1 Department of Molecular and Translational Medicine, Division of Pharmacology, University of Brescia, \\ 25123 Brescia, Italy; giuseppina.maccarinelli@unibs.it (G.M.); sara.bonini@unibs.it (S.A.B.); \\ m.premoli002@unibs.it (M.P.); f.aria@unibs.it (F.A.); alessandra.gianoncelli@unibs.it (A.G.); \\ maurizio.memo@unibs.it (M.M.) \\ 2 Department of Neurobiology, Care Sciences and Society, Center for Alzheimer Research, Division of Clinical \\ Geriatrics, Karolinska Institutet, 14183 Huddinge, Sweden; amit.kumar@ki.se \\ * Correspondence: andrea.mastinu@unibs.it; Tel.: +39-030-371-7530 \\ + Authors equally contributed to this work.
}

Received: 19 March 2019; Accepted: 15 April 2019; Published: 17 April 2019

\begin{abstract}
Zeolites are porous minerals with high absorbency and ion-exchange capacity. Their molecular structure is a dense network of $\mathrm{AlO}_{4}$ and $\mathrm{SiO}_{4}$ that generates cavities where water and other polar molecules or ions are inserted/exchanged. Even though there are several synthetic or natural occurring species of zeolites, the most widespread and studied is the naturally occurring zeolite clinoptilolite (ZC). $\mathrm{ZC}$ is an excellent detoxifying, antioxidant and anti-inflammatory agent. As a result, it is been used in many industrial applications ranging from environmental remediation to oral applications/supplementation in vivo in humans as food supplements or medical devices. Moreover, the modification as micronization of ZC (M-ZC) or tribomechanically activated zeolite clinoptilolite (TMAZ) or furthermore as double tribomechanically activated zeolite clinoptilolite (PMA-ZC) allows improving its benefits in preclinical and clinical models. Despite its extensive use, many underlying action mechanisms of ZC in its natural or modified forms are still unclear, especially in humans. The main aim of this review is to shed light on the geochemical aspects and therapeutic potentials of $\mathrm{ZC}$ with a vision of endorsing further preclinical and clinical research on zeolites, in specific on the ZC and its modified forms as a potential agent for promoting human brain health and overall well-being.
\end{abstract}

Keywords: zeolite clinoptilolite; micronization; tribomechanical activation; detoxifying; antioxidant; anti-inflammatory; Alzheimer disease

\section{Introduction}

Zeolites represent a family of hundreds of microporous mineral members known for their ion-exchange properties [1]. The term "zeolite" coined in 1756 by the Baron Axel Fredrik Cronstedt, a Swedish mineralogist and chemist, derives from the Greek language $\zeta \dot{\varepsilon} \omega$ ("zeo", to boil) and $\lambda{ }^{i} \theta 0 \varsigma$ ("lithos", stone) meaning "boiling stone". The structure of the zeolites mainly consists of alumino-silicates with $\mathrm{SiO}_{4}$ and $\mathrm{AlO}_{4}$ structures connected by shared oxygen atoms [2]. Clinoptilolite is one of the most abundant natural zeolites, widely distributed throughout the world and used for its ion exchange and adsorbent properties [3]. Thanks to its remarkable and unique ion-exchange properties in water, it has been employed for various medical, industrial and environmental uses, in particular, for sequestration of toxic pollutants from industrial effluent and wastes [3]. At present, many positive effects are recognized due to the capacity of natural occurring zeolite clinoptilolite (ZC) to adsorb and therefore remove harmful substances like heavy metals, ammonia, or other small molecules in the 
gastrointestinal tract of humans. It is important to mention that this positive impact can improve through modifications of ZC due to micronization of ZC (M-ZC) or tribomechanical activation of ZC (TMAZ) or double tribomechanical activation of ZC (PMA-ZC), known as Panaceo Micro Activation [4]. This recently developed PMA (Panaceo Micro Activation)-technology is a special tribomechanical micronization process that causes self-collisions of zeolite particles and contributes to increasing the surface charge and the cation exchange of the individual particles, improving the overall therapeutic performance of ZC [5]. The oral application of the specific PMA-zeolite in a randomized clinical trial in humans furthermore suggests having a positive impact on the intestinal tract as it positively influenced the intestinal wall integrity [6]. Preclinical data furthermore suggest a positive impact on the intestinal microbiome [7]. This connection might be interesting as recent studies have established a possible link between the gut microbiome and chronic neurological disorders. This possible link has been termed as the "Gut-Brain Axis" [8].

In order to gain a better understanding of natural zeolite minerals and their therapeutic action and some side effects, it is essential to study their geological origin, chemical composition, and structure. This review will focus on exploring the geo-chemical aspects of naturally occurring zeolite clinoptilolite (ZC) without any modification-referred to either as ZC or "natural zeolite" or "zeolite" in this article. Furthermore, the focus will be on the modified forms of ZC (M-ZC, TMAZ, PMA) by highlighting its therapeutic aspects and with the aim of promoting further research on $\mathrm{ZC}$ for overall human well-being and as a potential preventive agent in Alzheimer disease and other neurological disorders.

\section{Where Do Zeolites Come From?}

The geological formation of natural zeolite indifference to synthetic zeolite involves different rock species, in particular, physio-chemical conditions of temperature and pressure. These rock species could vary from volcanic to plutonic rocks $[9,10]$. Below the surface of the earth, magma releases heat, modifying the structure of plutons previously solidified in specific contact areas known as aureoles. In these aureoles, different porous zeolite mineral formations take place upon deposition of water, for example, as in the porous tephra, which is produced by viscous magma with a high content of silicon, or as in the volcaniclastic sediments or in the feldspathic sandstone [9]. In nature, the genesis of several zeolite species depends on the type of minerals present (for example, an acid or basic volcanic glass) which characterize its structure. Zeolite rocks are particularly widespread throughout the earth's crust, particularly in the Cenozoic and Mesozoic layers and clinoptilolite is considered as the most common naturally occurring zeolite mineral [11-15]. Zeolites are distributed mainly in regions with a past volcanic history or areas still geologically active today [11]. Indeed, stratigraphy belonging to different geological eras ranging from Tanzawa Mountains (Japan) to Yellowstone Park (USA), from Tecopa Lake Beds in Southern California to the Eocene Wagon Bed Formation in Wyoming, from Paleogene and Cretaceous calcareous sediments in the Atlantic and Pacific Ocean to bituminous sediments in dolomitic shale, are rich in natural zeolite-clinoptilolite [16]. On the other hand, hydrothermal zeolites are mainly found in the newer orogenic belts and hot spots where heavy deposition and recent volcanic events occurred, such as in the Tethys regions including France, Italy, Switzerland and Slovenia [17,18]. Moreover, the process of zeolite formation from feldspathic rocks called "zeolitization" is still ongoing in active volcanic areas and even today we can witness these zeolitic transformations in volcanic regions with thermal water sites $[19,20]$. From a chemical point of view, zeolites show certain chemical stability in aqueous solutions at different $\mathrm{pH}$ values [20]. The clinoptilolite structure shows high thermal stability which is essential for human applications. It is still not destroyed after heating $12 \mathrm{~h}$ at $750{ }^{\circ} \mathrm{C}$ [21]. The presence of hydrogen and hydroxyl ions in solution generate physical-chemical phenomena such as hydrolysis, degradation, dissolution and phase transformation which help in the characterization of different types of mineral zeolites. The zeolites have a microporous network composition consisting of tetrahedral of $\mathrm{AlO}_{4}$ and $\mathrm{SiO}_{4}$ joined by shared oxygen atoms [22] (see Figure 1). 

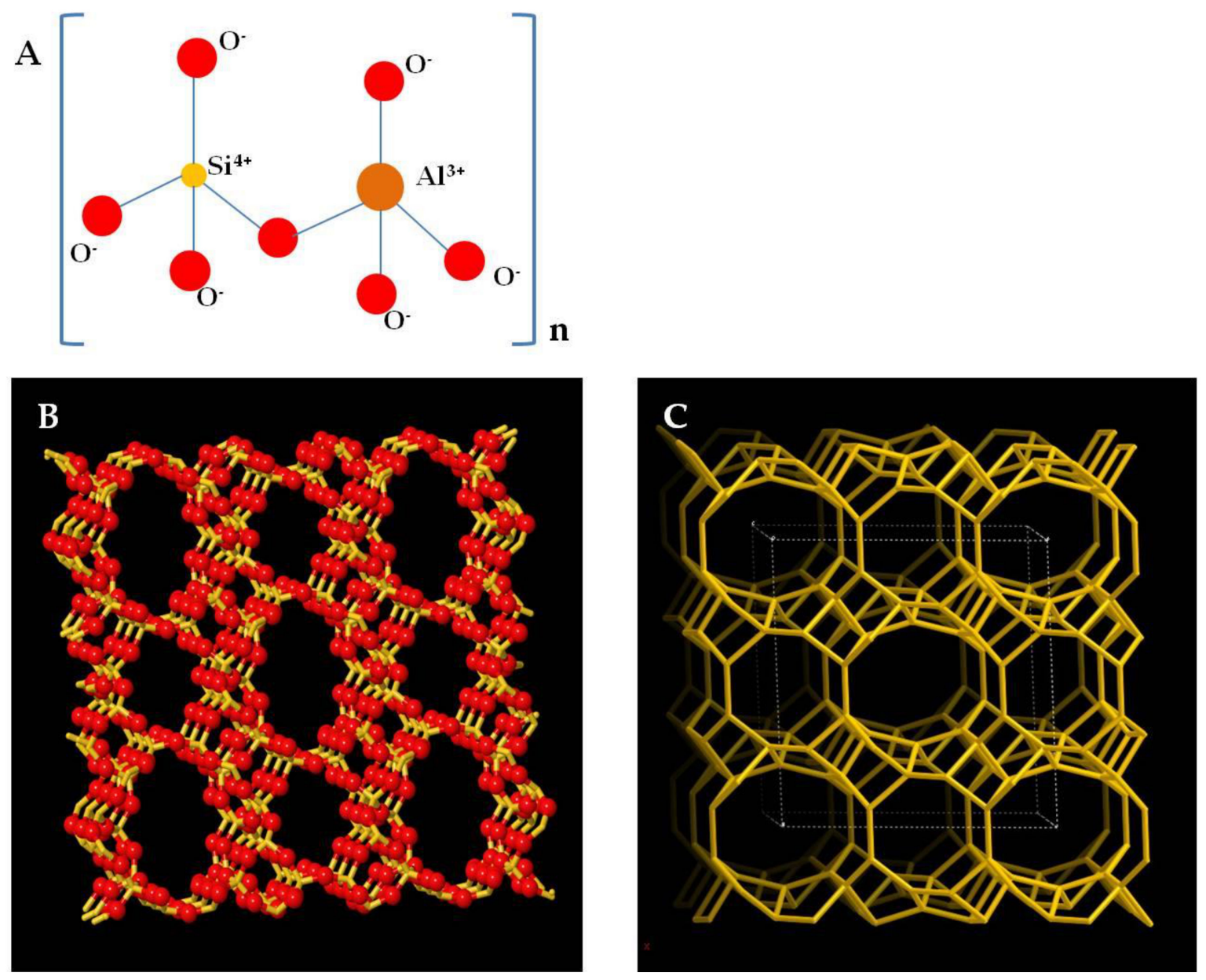

Figure 1. (A) $\mathrm{AlO}_{4}$ and $\mathrm{SiO}_{4}$ tetrahedrons joined by oxygen atoms that constitute the reticular structure of the zeolite. (B) and (C) Clinoptilolite framework type by http://www.iza-structure.org/.

In nature, there are more than 80 different types of zeolites, whose particles can be grouped in crystalline structure with a fibrous, lamellar or spheroid morphology [23]. These types of zeolite (Figure 2) show different characteristics and applications summarized in Table 1. The most widely used and diffused zeolite is ZC. The whole structure of ZC is made of pores or channels with a uniform shape in which the substances can be adsorbed. In particular, water, or polar molecules, are inserted into these pores that act as sieves for molecules that interact with zeolites by dipolar interactions [22]. In addition to water, the cavities and channels are also occupied by monovalent alkaline ions, such as sodium and potassium, and divalent atoms such as calcium and barium, or hydroxyl groups that can easily be exchanged with other polar molecules and cations from the surrounding environment [24]. The zeolites ion exchange capacity and cationic exchange within its pores/channels mainly depend on its silicon and aluminum ratio [24]. This ratio is furthermore important for the stability of ZC. It has been documented that zeolites with higher silica content, such as clinoptilolite, are stable under acid conditions [25]. In vivo experiments with TMAZ and PMA-ZC proved stability in particular to possible aluminum ions leakage into the body under the conditions of the gastrointestinal tract. These experiments confirm the safety as no increased aluminum ions concentrations were detected neither in serum nor in organs of animals after supplementation with PMA-ZC and TMAZ [4]. The pores of the $\mathrm{ZC}$, in addition to metal cations and water, can interact with other molecules and ionic groups of organic origin, such as ammonia and nitrates, which bind with different levels of affinity [26,27]. Thanks to these exceptional ion interactions properties, ZC is considered as one of the key important inorganic cation exchangers and heavily applied in many industrial sectors such as in the treatment of waste-water, nuclear waste, cultivated fields, animal husbandry, or as oral supplementation in 
humans [5]. The ability to interchange ions leaves open some questions about the selectivity of ZC. Indeed, the impossibility of ZC to absorb useful ions for health still needs to be clearly demonstrated.

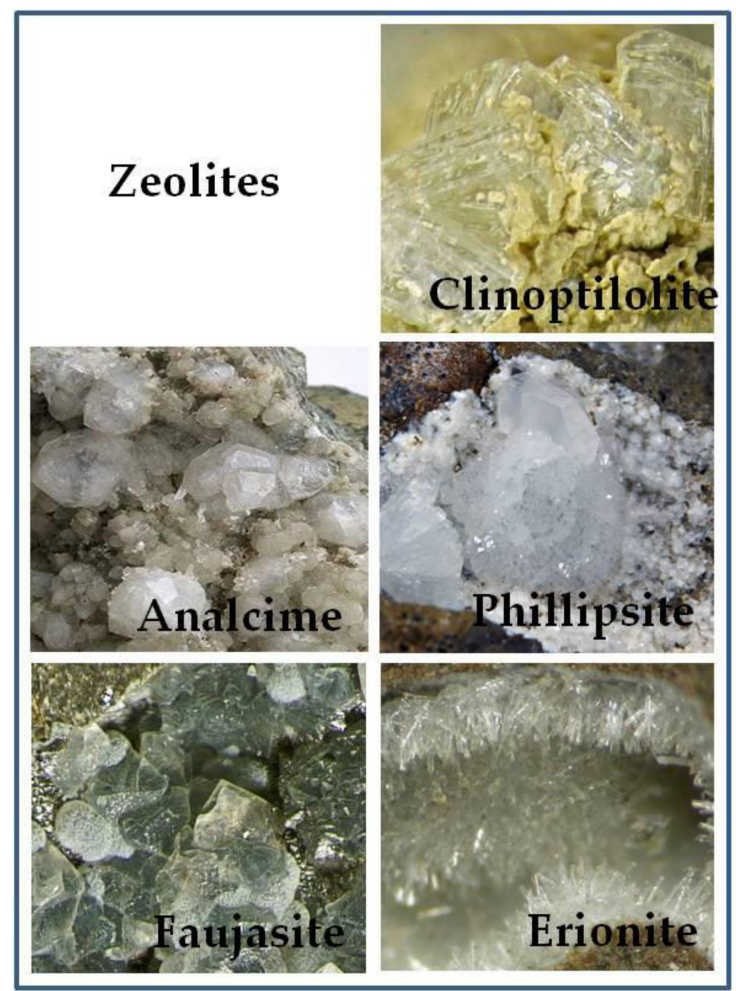

Figure 2. Some minerals with zeolite structure. Clinoptilolite photo by Christian Rewitzer Collection (CC BY-SA 3.0); Analcime photo by Carles Milan (CC BY 3.0); Phillipsite photo by Martin Zinn (CC-BY-SA-3.0); Faujasite photo by Modris Baum (Public Domain); Erionite photo by Leon Hupperichs (CC BY-SA 3.0).

Moreover, not all types of zeolite are safe. In particular, it has been found that zeolite erionite is associated with lung cancer and malignant mesothelioma [28,29]. In particular, erionite forms fragile wool-like fibrous masses in the cavities of rock formations [10] and shows properties similar to those of asbestos as malignant mesothelioma development in humans [30]. Mesothelioma is a tumor that originates from the mesothelial cells that line the pleural, pericardial and peritoneal surfaces. Some studies have reported that continued exposure to erionite fiber dust has been the cause of deaths in some villages in Turkey [31]. These important side effects of zeolite have been abundantly documented only for the erionite type. Other fibrous zeolites such as offretite and scolecite can alter some mitochondrial mechanisms and the organization of the cellular structure [32]. This review has focused its attention on $Z C$, a natural zeolite which showed no toxic effects but potential therapeutic applications. Despite the absence of toxicity of $Z C$, some authors have highlighted potential side effects that must be considered when using ZC [5,33]. In particular, ZC reduced cell viability and DNA synthesis and increased cell apoptosis in in vitro models [34]. ZC has reduced the functionality of key proteins involved in cell survival and apoptosis in tumor cell lines. This action on tumor cell lines has been attributed to the absorptive and ion-exchange capacities of ZC that can modify the concentration of calcium ions and affect the Ca-dependent molecular signals. The main characteristic of ion exchanger of the ZC can represent a criticality that needs further study to evaluate all the benefits of this food supplement. 
Table 1. Characteristics and biological effects of some types of zeolite.

\begin{tabular}{cccc}
\hline Zeolite Mineral Species & Formula & Effects & Ref. \\
\hline Analcime & $\mathrm{NaAlSi}_{2} \mathrm{O}_{6} \cdot \mathrm{H}_{2} \mathrm{O}$ & Antioxidant & {$[35]$} \\
Phillipsite & $\left(\mathrm{Ca}, \mathrm{Na}_{2}, \mathrm{~K}_{2}\right)_{3} \mathrm{Al}_{6} \mathrm{Si}_{10} \mathrm{O}_{32} \cdot 12 \mathrm{H}_{2} \mathrm{O}$ & Antioxidant and gut microbiota & {$[35,36]$} \\
Faujasite & $\left(\mathrm{Na}_{2}, \mathrm{Ca}, \mathrm{Mg}\right)_{3.5}\left[\mathrm{Al}_{7} \mathrm{Si}_{17} \mathrm{O}_{48}\right] \cdot 32\left(\mathrm{H}_{2} \mathrm{O}\right)$ & Antimicrobial & {$[37]$} \\
Erionite & $\left(\mathrm{Na}_{2}, \mathrm{~K}_{2}, \mathrm{Ca}\right)_{2}\left[\mathrm{Al}_{4} \mathrm{Si}_{14} \mathrm{O}_{36}\right] \cdot 15 \mathrm{H}_{2} \mathrm{O}$ & $\begin{array}{c}\text { Carcinogenic } \\
\text { Environmental purification, }\end{array}$ & {$[28-30,38]$} \\
Clinoptilolite & $(\mathrm{Na}, \mathrm{K}, \mathrm{Ca})_{2-3} \mathrm{Al}_{3}\left(\mathrm{Al}, \mathrm{Si}_{2}\right)_{2} \mathrm{Si}_{13} \mathrm{O}_{36} \cdot 12 \mathrm{H}_{2} \mathrm{O}$ & $\begin{array}{c}\text { intestinal detoxifier, antioxidant, } \\
\text { anti-inflammatory, antitumor }\end{array}$ & {$[39-43]$} \\
\hline
\end{tabular}

\section{Zeolite Clinoptilolite: A Multifaceted Rock}

$\mathrm{ZC}$ is the zeolite most used and studied in medicine and in particular, the ZC tribomechanically micronized one (TMAZ) or two times (PMA) with PMA technology (PMA-ZC) showed some preclinical and clinical evidences $[4,5,44,45]$. Several studies conducted in the last decades have shown high efficacy of ZC in various medical applications both in vitro and in vivo. Moreover, different processing procedures are responsible for substantial changes in the physical-chemical properties like absorbent characteristics or ion-exchange capacities or the surface area of ZC. Those can be improved thanks to particular treatments such as micronization or the particular tribomechanical micronization. For human applications, it is important to use ZC which is considered safe for oral applications in humans. Recently published data suggest that the PMA-ZC show improved physical-chemical properties might be a safe option [5]. This improved physical-chemical properties seem to be the basis of its therapeutic virtues.

In this section, the characteristics of different modified ZCs and their therapeutic applications will be discussed.

\subsection{Micronized Zeolite Clinoptilolite: A Special Treatment}

The micronization of zeolite clinoptilolite $(\mathrm{M}-\mathrm{ZC})$ is a procedure that breaks down the ZC into small parts accentuating its detoxifying characteristics [44]. This micronization occurs with mills having two counter-rotating parallel blades, which, with a thrust of $2500 \mathrm{~km} / \mathrm{h}$ and particular aerodynamics, create two counter-rotating airflows [46]. This ZC powder is distributed in the two airflows and begins to self-collide with a frequency of 3-4000 collisions/s [46]. Furthermore, tribomechanical micronization is a specific micronization first used to activate $\mathrm{ZC}$ one time-TMAZ and was further developed as Panaceo Micro Activation technology with PMA-ZC as a result [6]. Thus obtained, it underwent a very strong ionic excitement, which increased its surface charge and detoxifying capacity towards toxins, radicals, ammonia, and heavy metals [5]. However, the main element is given by the structural modification making the PMA-ZC much more active in the "recall" in the intestinal lumen. In fact today, PMA-ZC is prescribed for absorbing/chelating and removing harmful and toxic substances from the gastrointestinal tract (e.g., heavy metals, nitrosamines, ammonia, mycotoxins, cations, radioactive materials, pesticides), reducing their absorption in the body [4,6]. In addition, a clinical study shows that it strengthens the intestinal wall which might be based on its absorbing properties [6]. Finally, it can also function as an anti-oxidant by capturing free radicals and reducing the formation of reactive oxygen species, as discussed below.

\subsection{Detoxifying Effects}

Most of the clinical positive effects of $\mathrm{ZC}$ and modified $\mathrm{ZC}$ have been attributed to its reversible ion exchange and adsorption capacity. The first detoxifying effects of $Z C$ in a modified form were observed in murine models. In lead poisoned mice, the modified ZC reduced the accumulation of lead in the intestine by more than $70 \%$ with a protective effect on the brain tissue [47]. In rats intoxicated with organophosphates, ZC was effective in restoring cholinesterase activity at the system level [48,49]. According to some reports, $\mathrm{ZC}$ in the intestine could bind to the organophosphate through an interaction with an $-\mathrm{OH}$ group or a dipole-dipole interaction and therefore can be excreted in the feces [50]. 
As a result, the role of $\mathrm{ZC}$ has been recognized in zootechnics and veterinary medicine where it has provided clear evidence on improving the physical fitness and efficiency of farm animals by removing numerous harmful substances from the body including ammonia, nitrates, mycotoxins, and other toxins [51]. The presence of ammonia and polar molecules in the environment is the result of intensive zootechnical and agricultural activities that pour these pollutants into the environment, contaminating our groundwater resources. ZC has shown a high ability to eliminate ammonia from the environment, especially from drinking water [3]. Moreover, today it has also been used in the reclamation of animal manure before soil contamination [52]. In addition, dairy cattle may undergo nitrate and mycotoxins intoxication from the water, which can generate alterations in protein and glucose metabolism [53]. In these cows, the integration of ZC in the feed has reduced the assimilation of nitrates and concentration of aflatoxins in their milk, improving the systemic toxic effects [53,54]. The detoxifying action on these ions has no effect on the physiological ionic equilibrium. In fact, the blood mineral levels of cattle were unaffected by integration with ZC [55]. In addition, similar beneficial effects have also been observed in other farm animals such as pigs and poultry. In this regard, ZC has shown a positive effect in farmed poultry in balancing the total intestinal microbial flora, reducing toxic effects of aflatoxins and increasing the antioxidant activity (see below) of peroxidase, catalase, and SOD (superoxide dismutase) as well as increasing levels of omega-3 fatty acids in eggs [56-58]. The physical-chemical properties and therefore detoxifying abilities improve when ZC is subjected to PMA technology as observed in some clinical settings. In particular, the detoxifying action of PMA-ZC towards ammonia may have potential applications as a therapeutic adjuvant in humans as hypothesized based on results from a clinical study [5,6]. Ammonia is produced as a waste in the body during the metabolism of proteins, transformed by the liver into urea, and eliminated by kidneys [59]. Diets rich in proteins, pathologies with excessive protein fermentation, as in the case of irritable bowel and ulcerative colitis lead to an increase in the production of ammonia [59]. High levels of ammonia indicate poor hepatic and renal function. Some authors have highlighted the important ammonia detoxifying contribution of $Z C$ in various diseases [60]. In particular, a study focused on the administration of specific PMA-ZC (Panaceo Sport) to endurance-trained subjects who probably undergo a rich protein diet and frequently encounter intestinal symptoms such as nausea, stomach, and intestinal cramps, vomiting, and diarrhea [6]. These annoying conditions can result from the excessive protein fermentation accompanied by the higher release of ammonia in the intestine. Excessive exercise can also compromise the same intestinal permeability and trigger cell-mediated inflammatory responses [61]. Supplementation with PMA-ZC improved the integrity of the intestinal barrier, decreasing the concentrations of zonulin, a marker of increased intestinal permeability and might furthermore have positive effects on nausea and diarrhea (Figure 3) [6]. Despite these pieces of evidence on the detoxifying action of $\mathrm{ZC}$, there are still few clinical studies in humans. The ability to interchange ions of $\mathrm{ZC}$ raises some questions regarding the risk of altering the homeostasis of necessary trace elements and micronutrients in humans [62]. Indeed, despite studies of the use of PMA-ZC in athletes not revealing any alterations in the hydro-saline equilibrium, further investigations are necessary for human use.

\subsection{Anti-Inflammatory Effects}

Different hypotheses and recently published reports have explained the anti-inflammatory effects of ZC, some of these reports highlighting the relationship between PMA-ZC and the site of action at the intestinal level. The mucosa-associated lymphoid tissue (MALT) and the gut-associated lymphoid tissue (GALT) are the sites where the main intestinal cell-mediated inflammatory responses are modulated [63]. These two tissues are composed of M cells, highly specialized cells, overlying lymphatic nodules called Peyer's patch [63]. The M cells by endocytosis acquire bacteria, soluble and solid substances through the apical membrane and transport them by means of vesicles to the basolateral membrane where they are released by exocytosis and processed by macrophages. Macrophages present the antigen to T-lymphocytes, which stimulate IgA production [63]. TMAZ immunomodulatory effects may be due 
to interactions with M cells [64]. Indeed, M cells could interact with ZC particles tribomechanically activated, which could then induce changes in the redox homeostasis and affect Peyer's patches. These absorbed microparticles do not pass to the bloodstream, but act locally in this district as hypothesized by Lamprecht and colleagues [6]. The action of PMA-ZC on intestinal lymphoid tissues (positive impact on IL-10) was also observed in the metabolites released by probiotics capable of improving the intestinal ecosystem and boosting the immune system $[65,66]$. Sabbioni and colleagues have observed, in experimental animal models treated with a particular zeolite, chabazitic zeolites, an increase in the production of B-lymphocytes and IgA [67], the main defensive mechanisms of the intestine against pathogenic bacteria [68]. IgA plays a fundamental role in modulating the pro-inflammatory response. Indeed, IgAs balance the body's immune response to the intestinal microbial flora, helping in the adaptation towards bacteria already present and detecting the presence of new ones [69]. Furthermore, the immunomodulatory action of ZC such as also for TMAZ or PMA-ZC would occur at this level, acting, perhaps, as a superantigen. Superantigens are particular molecules of peptidic or oligo-protein nature capable of directly stimulating a significant and non-specific immune system response [70]. This immuno activation/stimulation happens immediately after the interaction of superantigen with the class II MHC (major histocompatibility complex) molecules and the T-lymphocytes receptors [71]. Then, superantigens activate the T-lymphocytes, which induce the cellular and humoral immune response [70,71]. Even though the stimulation of lymphocytes by zeolites has been demonstrated only in vitro, the mechanism of IgA production after stimulation of T-lymphocytes by ZC can be considered as a valid hypothesis. Finally, other immunomodulatory effects of TMAZ, PMA-ZC, and other zeolites cannot be excluded, but this topic needs further investigation. For instance, a remarkable increase in specific immune cell counts, CD19C B-lymphocytes, CD4C T-lymphocytes, and HLA-DRC activated T-lymphocytes were also observed in patients treated for immunodeficiency and receiving TMAZ, which is similar to PMA-ZC due to the tribomechanical activation with no reports of any significant side effects on the immune system after treatment [64].

\subsection{Antioxidant Effects}

The enzymatic systems that regulate the homeostasis of the redox system in the body are the superoxide dismutase (SOD), catalase, peroxiredoxin, thioredoxin and glutathione (GSH) enzymes [72]. An excess of reactive oxygen species (ROS) produced at the endogenous level by the mitochondria, by cytochrome P450, and by inflammatory cells, or exogenously generated by ionizing radiations, causes damage to DNA, proteins, and lipids [73]. This process is called oxidative stress and is involved in various diseases including obesity, atherosclerosis, neurological diseases, and cancer [74]. The antioxidant capacity of micronized ZC is based on its ability to avail metal ions present within its structure as cofactors for the activation of antioxidant enzymes. In this regard, the most important data were obtained using animal models. In particular, Saribeyoglu and colleagues hypothesized antioxidant properties of ZC towards hepatectomy induced by oxidative stress in rats [75]. Indeed, these rats showed an increase of SOD and GSH activity after ZC treatment. Also, administration of M-ZC and TMAZ reduced hepatic lipid peroxidation in mice treated with doxorubicin [44]. Furthermore, ZC restored the activity of antioxidant enzymes in murine models intoxicated with fluorides [76]. In chickens receiving daily ZC in food, antioxidant capacity was increased by reducing the free radical content of intestinal nitric oxide and increasing the activity of GSH, catalase and SOD enzymes [77-79]. Finally, the TMAZ (similar to PMA-ZC) has shown a particular antioxidant action in murine models of Alzheimer's disease. In particular, the increase in SOD activity also occurred in the brain with a consequent decrease of $\beta$-amyloid levels in transgenic mouse models of Alzheimer's disease after treatment with TMAZ [45]. Despite these results on animal models, still few studies showed a clear effect of all ZC on redox systems in humans. For instance, the integration of PMA-ZC in sports nutrition has no effect on the production of free radicals [6]. In this regard, some studies hypothesize that the antioxidant effect may be a consequence of the detoxifying effects of PMA-ZC at the intestinal and systemic levels which are not always quantifiable [5]. For this reason, further human studies are 
necessary to understand the effective contribution of all zeolite stones to our redox balance. In particular, further data with already authorized zeolites for oral supplementation (e.g., PMA-ZC) would be useful.

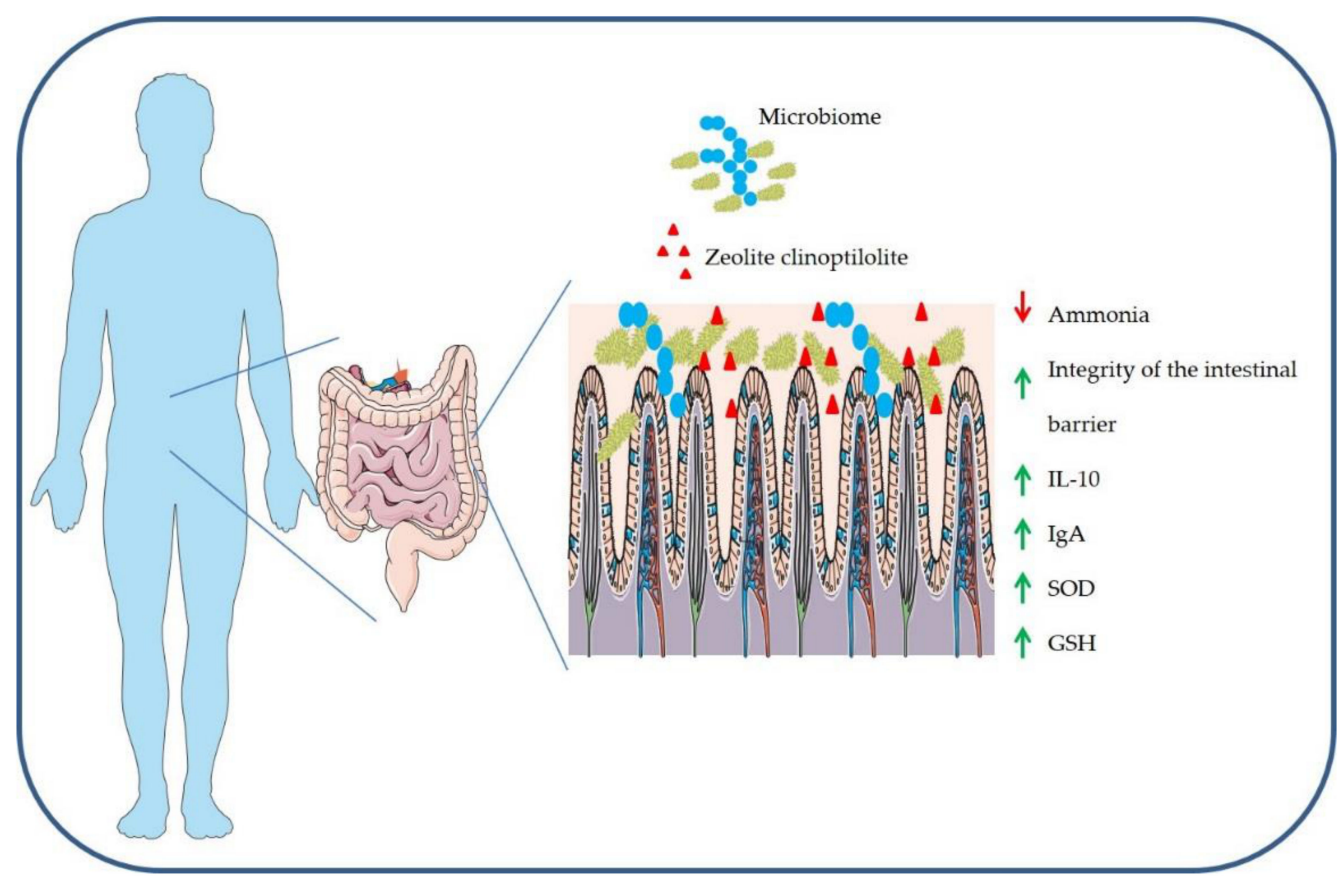

Figure 3. Zeolite clinoptilolite $(\mathrm{ZC})$ reduces ammonia concentration and improves the integrity of the intestinal barrier. Furthermore, ZC acts on intestinal lymphoid tissues with a positive impact on the intestinal ecosystem and boosting the immune system. ZC avails metal ions, present within its structure, as cofactors for the activation of antioxidant enzymes.

\section{Brain Effects of Zeolite Clinoptilolite}

Given the existence of the gut-brain interconnection, it has been hypothesized that an indirect action of ZC exists at the level of the central nervous system. In this regard, some recent hypotheses are discussed below.

\subsection{What is the Action of Zeolites in the Brain?}

In the pharmacological field, there are so many treatments which have beneficial effects but their underlying molecular mechanisms are still unknown [80]. The same could be true for zeolites. According to Hecht K. and colleagues, ZC is able to reduce stress and improve sleep, producing a soothing effect in humans [81]. To date, the neurological and molecular bases for these soothing effects are still puzzling researchers. Perhaps an answer can come from studies of the murine models. In fact, Mück-Šeler and colleagues have shown that TMAZ can abolish the reduced binding of 3H-8-OH-DPAT to 5-HT1A receptor in cancer mice models and produce possible beneficial effects [82]. Furthermore, a behavioral study showed that the rats react better to environmental stress if their food is supplemented with ZC [83]. As zeolites do not cross the intestinal barrier, and not even the blood-brain barrier when the particles are big enough (no nanoparticles), this suggests an indirect mechanism that acts remotely (gut?) and positively on the brain. For this reason, some authors have hypothesized the possibility of zeolites-in this case, as nano-materials that would be able to cross barriers (intestinal or even blood-brain-barrier) to transport neurotransmitters, peptides, antibiotics, exploiting their capacity of ion exchangers [84-87]. Unfortunately, this hypothesis is not without difficulties and criticalities. Therefore, these observations on the effects of ZC remain hypotheses for potential applications that will require further in-depth studies. 


\subsection{Zeolites, Gut-Brain Axis and Alzheimer Disease}

Alzheimer disease $(\mathrm{AD})$ is a progressive neurodegenerative disorder and the most prevalent form of dementia affecting millions of people worldwide with no potential cure or treatment in sight [88]. As all the recent clinical trials are failing in final phases, researchers are looking for alternate ways to combat and contrast this deadly disease [89-92]. One of the ways is to prevent the progression of the disease by promoting a healthy lifestyle through a combination of balanced diet and exercise, as recent studies have established a possible link between the gut microbiome and the chronic neurological disorders [93-96]. This possible link has been termed as the "Gut-Brain Axis" [8]. Moreover, several studies have shown that the altered or abnormal gut microbiome due to an unhealthy lifestyle could affect intestinal permeability, which may be involved in the progression of AD and several other neurological disorders [97-99]. In addition, diets rich in fibers, fruits, and vegetables are more effective in maintaining gut homeostasis/integrity and delaying AD development as compared to a western diet rich in high-fat, red meat and processed food [100]. In this regard, specific authorized ZC, like PMA-ZC which is the further developed TMAZ for human applications, could represent good alternatives in AD patients as they possess detoxifying, antioxidants, anti-inflammatory, and gut-protective properties. A study performed by Montinaro and colleagues, using TMAZ showed protective effects against oxidative stress (Figure 4) and plaque burden in transgenic mice models of AD [45]. They suggested that the protective effect of TMAZ - further developed as PMA-ZC could be due to its ability to maintain gut electrolyte equilibrium. Even though this study showed the extensive potential of TMAZ/PMA-ZC in $\mathrm{AD}$, it is still an unexplored domain and several new and extensive studies (biochemical, preclinical and clinical) are needed to establish its prominent role as a preventive treatment in AD and other neurological disorders.

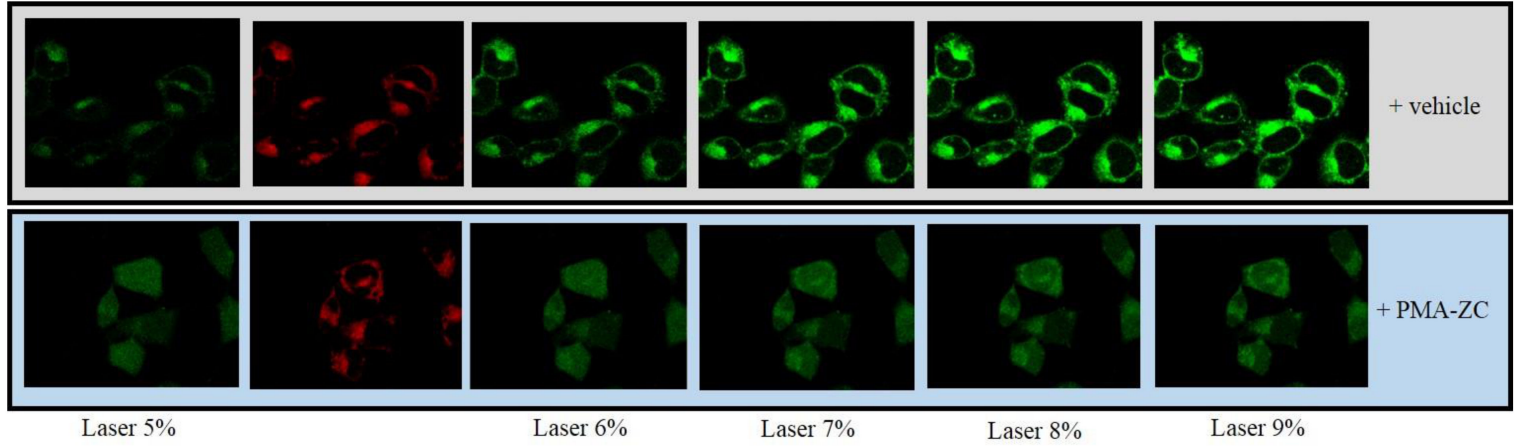

Figure 4. Mitochondrial ROS production in SH-SY5Y neuronal cells. In this particular set of images, a set of cells (lower panels) were preincubated with tribomechanically activated zeolite (TMAZ) and Panaceo Micro Activation (PMA-ZC) (2,5 ng/mL) or vehicle (upper panels) for $30 \mathrm{~min}$ before the laser excitation. Cells pretreated with TMAZ/PMA-ZC were more protected from oxidative stress than cells that received only vehicle (adapted from Montinaro et al., 2013).

\section{Conclusions}

The physical-chemical properties of ZC are essential for the absorbing characteristics or ion-exchange, and therefore, for its therapeutic potential. Indeed, the rock mixtures that constitute the natural mineral form complexes of aluminum and silicon which allow the formation of cavities inside where inorganic and organic polar or metal ions are deposited or exchanged. This exceptional ion-exchange capacity, as well as the surface area, are improved with micronization processes, in particular with the tribomechanical micronization processes used for TMAZ or PMA-ZC. In particular, thanks to PMA technology, ZC is activated and its absorbing capacities increase. ZC, in general, is known as an environmental decontaminant and specific TMAZ and PMA-ZC have found multiple applications in the last 20 years. The most important is its oral use for supplementation in humans. Environment decontamination from heavy metals derived from industrial waste or from 
organic molecules derived from intensive farming is essential for biological ecosystems. Due to the binding capacities, ZC has been generally used in the zootechnical field for water purification and decontamination, contributing to the improvement of livestock health. Furthermore, environmental contaminants accumulate throughout the food chain and are therefore part of foodstuff. For this reason, PMA-ZC is studied and used for oral supplementation to bind toxic substances such as ammonia or heavy metals in the milieu of the gastro-intestinal tract. Furthermore, PMA-ZC is capable of improving the ecosystem of intestinal microbial flora. Based on the data collected on animal models and on a few clinical trials, it can be speculated that the general state of wellbeing generated by $\mathrm{ZC}$, and in particular by TMAZ and PMA-ZC, is due to its detoxifying, anti-inflammatory and antioxidant action in the intestine. Indeed, recent findings of the importance of the gut microbiome in the regulation of immunity and its interconnection with the central nervous system could at least partially explain the results obtained using animal models treated with PMA-ZC. ZC could purify the internal environment of our body, maintain gut microbiota homeostasis for healthy brain activity, improve the antioxidant and endogenous anti-inflammatory activities thereby improving the overall wellbeing of the patient. Despite all this, still, only a few studies have defined the molecular mechanisms underlying the positive effects of all ZC. Furthermore, several important questions are still unanswered: What is the molecular mechanism that increases the antioxidant activity of SOD and GSH in experimental models treated with ZC? What is the translational value of the action of ZC on $\beta$-amyloid levels? Is there risk of reducing the contribution of mineral salts due to the ion exchange action of $Z C$ ? Finally, is there remote danger of ZC crossing the intestinal wall?

In conclusion, preclinical research on zeolites was not aimed at finding a new drug, but a food supplement that can improve lifestyle and be combined with traditional pharmacological treatment. In fact, recent evidenced suggested a promising detoxifying role of ZC in the removal of toxic metabolites produced by drugs chronically administered during chemotherapy, diabetes, or cardiovascular diseases. However, new and extensive research will be needed to explore all the potential benefits that $\mathrm{ZC}$ and other specific modified ZC can produce on human health.

Author Contributions: A.K. reviewed and edited the manuscript for English language, M.P. and F.A. wrote the geochemical aspects, S.A.B. and G.M. wrote all pharmacological aspects, A.G. wrote all chemical aspects, and M.M. and A.M. conceived, designed and wrote the manuscript. All authors read and approved the manuscript.

Funding: This work was supported by "Research Grant from the University of Brescia EX60\%MEMO" and "Petrus och Augusta Hedlunds Stiftelse; Loo och Hans Ostermans Stiftelse; Karolinska Institutet Research and Geriatrics Foundation; Gunvor och Josef Aners Stiftelse; Tore Nilson Stiftelse and Lars Hiertas Minne Stiftelse".

Conflicts of Interest: The authors declare no conflict of interest.

\section{References}

1. Pekov, I.V.; Grigorieva, A.A.; Turchkova, A.G.; Lovskaya, E.V. Natural ion exchange in microporous minerals: Different aspects and implications. Miner. Adv. Mater. I 2008, 7-15. [CrossRef]

2. Jha, B.; Singh, D.N. Basics of Zeolites. In Fly Ash Zeolites; Springer: Singapore, 2016; Volume 78, pp. 5-31.

3. Margeta, K.; Zabukovec, N.; Siljeg, M.; Farkas, A. Natural Zeolites in Water Treatment-How Effective is Their Use. In Water Treatment; Elshorbagy, W., Chowdhury, R., Eds.; IntechOpen: London, UK, 2013; Volume 5, pp. 81-112.

4. Kraljević Pavelić, S.; Micek, V.; Filošević, A.; Gumbarević, D.; Žurga, P.; Bulog, A.; Orct, T.; Yamamoto, Y.; Preočanin, T.; Plavec, J.; et al. Novel, oxygenated clinoptilolite material efficiently removes aluminium from aluminium chloride-intoxicated rats in vivo. Microporous Mesoporous Mater. 2017, 249, 146-156. [CrossRef]

5. Kraljević Pavelić, S.; Simović Medica, J.; Gumbarević, D.; Filošević, A.; Pržulj, N.; Pavelić, K. Critical Review on Zeolite Clinoptilolite Safety and Medical Applications in vivo. Front. Pharmacol. 2018, 9, 1350. [CrossRef]

6. Lamprecht, M.; Bogner, S.; Steinbauer, K.; Schuetz, B.; Greilberger, J.F.; Leber, B.; Wagner, B.; Zinser, E.; Petek, T.; Wallner-Liebmann, S.; et al. Effects of zeolite supplementation on parameters of intestinal barrier integrity, inflammation, redoxbiology and performance in aerobically trained subjects. J. Int. Soc. Sports Nutr. 2015, 12, 40. [CrossRef] [PubMed] 
7. Wu, Q.J.; Wang, L.C.; Zhou, Y.M.; Zhang, J.F.; Wang, T. Effects of clinoptilolite and modified clinoptilolite on the growth performance, intestinal microflora, and gut parameters of broilers. Poult. Sci. 2013, 92, 684-692. [CrossRef]

8. Kaelberer, M.M.; Buchanan, K.L.; Klein, M.E.; Barth, B.B.; Montoya, M.M.; Shen, X.; Bohórquez, D.V. A gut-brain neural circuit for nutrient sensory transduction. Science 2018, 361, eaat5236. [CrossRef]

9. Iijima, A. Geology of Natural Zeolites and Zeolitic Rocks. Pure Appl. Chem. 1980, 52, 2115-2130. [CrossRef]

10. Mumpton, F.A.; Ormsby, W.C. Morphology of Zeolites in Sedimentary-Rocks by Scanning Electron-Microscopy. Clays Clay Miner. 1976, 24, 1-23. [CrossRef]

11. De'gennaro, M.; Cappelletti, P.; Langella, A.; Perrotta, A.; Scarpati, C. Genesis of zeolites in the Neapolitan Yellow Tuff: Geological, volcanological and mineralogical evidence. Contrib. Miner. Petrol. 2000, 139, 17-35. [CrossRef]

12. Gottardi, G. The Genesis of Zeolites. Eur. J. Miner. 1989, 1, 479-487. [CrossRef]

13. Li, Y.; Pera-Titus, M.; Xiong, G.; Yang, W.; Landrivon, E.; Miachon, S.; Dalmon, J.A. Nanocomposite MFI-alumina membranes via pore-plugging synthesis: Genesis of the zeolite material. J. Membr. Sci 2008, 325, 973-981. [CrossRef]

14. Machiels, L.; Garces, D.; Snellings, R.; Vilema, W.; Morante, F.; Paredes, C.; Elsen, J. Zeolite occurrence and genesis in the Late-Cretaceous Cayo arc of Coastal Ecuador: Evidence for zeolite formation in cooling marine pyroclastic flow deposits. Appl. Clay Sci. 2014, 87, 108-119. [CrossRef]

15. Woodall, L.J.; Anderson, P.A.; Armstrong, A.R.; Edwards, P.P. Dissolving alkali metals in zeolites: Genesis of the perfect cluster crystal. J. Chem. Soc. Dalton Trans. 1996, 719-727. [CrossRef]

16. Marantos, I.; Christidis, G.E.; Ulmanu, M. Zeolite Formation and Deposits. In Natural Zeolites Handbook; Inglezakis, V.J., Zorpas, A.A., Eds.; Bentham Science Publishers: Dubai, United Arab Emirates, 2012; Chapter 2.1; pp. 28-51.

17. Weisenberger, T.; Bucher, K. Zeolites in fissures of granites and gneisses of the Central Alps. J. Metamorph. Geol. 2010, 28, 825-847. [CrossRef]

18. Kovič, P.; Krošl-Kuščer, N. Hydrothermal Zeolite Occurrence from the Smrekovec Mt. Area, Slovenia, Yugoslavia. Stud. Surf. Sci. Catal. 1986, 28, 87-92.

19. Monzón, J.D.; Pereyra, A.M.; Conconi, M.S.; Basaldella, E.I. Phase transformations during the zeolitization of fly ashes. J. Environ. Chem. Eng. 2017, 5, 1548-1553. [CrossRef]

20. Hall, A. Zeolitization of volcaniclastic sediments; the role of temperature and pH. J. Sediment. Res. 1998, 68, 739-745. [CrossRef]

21. Ghiara, M.R. Occurrence of Clinoptilolite and Mordenite in Tertiary Calc-Alkaline Pyroclastites from Sardinia (Italy). Clays Clay Miner. 1999, 47, 319-328. [CrossRef]

22. Laurino, C.; Palmieri, B. Zeolite: "the Magic Stone"; Main Nutritional, Environmental, Experimental and Clinical Fields of Application. Nutr. Hosp. 2015, 32, 573-581.

23. Ivanova, I.I.; Knyazeva, E.E. Micro-mesoporous materials obtained by zeolite recrystallization: Synthesis, characterization and catalytic applications. Chem. Soc. Rev. 2013, 42, 3671-3688. [CrossRef] [PubMed]

24. Ambrozova, P.; Kynicky, J.; Urubek, T.; Nguyen, V. Synthesis and Modification of Clinoptilolite. Molecules 2017, 22, 1107. [CrossRef] [PubMed]

25. Benning, L.G.; Wilkin, R.T.; Barnes, H.L. Solubility and stability of zeolites in aqueous solution: II. Calcic clinoptilolite and mordenite. Am. Miner. 2000, 85, 495-508. [CrossRef]

26. Ham, K.; Kim, B.S.; Choi, K.-Y. Enhanced ammonium removal efficiency by ion exchange process of synthetic zeolite after $\mathrm{Na}+$ and heat pretreatment. Water Sci. Technol. 2018, 788, 1417-1425. [CrossRef] [PubMed]

27. Gorimbo, J.; Taenzana, B.; Muleja, A.A.; Kuvarega, A.T.; Jewell, L.L. Adsorption of cadmium, nickel and lead ions: Equilibrium, kinetic and selectivity studies on modified clinoptilolites from the USA and RSA. Environ. Sci. Pollut. Res. 2018, 25, 30962-30978. [CrossRef] [PubMed]

28. Giordani, M.; Mattioli, M.; Ballirano, P.; Pacella, A.; Cenni, M.; Boscardin, M.; Valentini, L. Geological occurrence, mineralogical characterization, and risk assessment of potentially carcinogenic erionite in Italy. J. Toxicol. Environ. Health Part B 2017, 20, 81-103. [CrossRef]

29. Beaucham, C.; King, B.; Feldmann, K.; Harper, M.; Dozier, A. Assessing occupational erionite and respirable crystalline silica exposure among outdoor workers in Wyoming, South Dakota, and Montana. J. Occup. Environ. Hyg. 2018, 15, 455-465. [CrossRef] 
30. Demirer, E.; Ghattas, C.F.; Radwan, M.O.; Elamin, E.M. Clinical and Prognostic Features of Erionite-Induced Malignant Mesothelioma. Yonsei Med. J. 2015, 56, 311-323. [CrossRef] [PubMed]

31. Metintas, S.; Ak, G.; Metintas, M. A review of the cohorts with environmental and occupational mineral fiber exposure. Arch. Environ. Occup. Health 2018, 74, 76-84. [CrossRef] [PubMed]

32. Cangiotti, M.; Salucci, S.; Battistelli, M.; Falcieri, E.; Mattioli, M.; Giordani, M.; Ottaviani, M.F. EPR, TEM and cell viability study of asbestiform zeolite fibers in cell media. Colloids Surf. B Biointerfaces 2018, 161, 147-155. [CrossRef] [PubMed]

33. Bacakova, L.; Vandrovcova, M.; Kopova, I.; Jirka, I. Applications of zeolites in biotechnology and medicine-A review. Biomater. Sci. 2018, 6, 974-989. [CrossRef] [PubMed]

34. Katic, M.; Bosnjak, B.; Gall-Troselj, K.; Dikic, I.; Pavelic, K. A clinoptilolite effect on cell media and the consequent effects on tumor cells in vitro. Front. Biosci. J. Virtual Libr. 2006, 11, 1722-1732. [CrossRef]

35. Dogliotti, G.; Malavazos, A.E.; Giacometti, S.; Solimene, U.; Fanelli, M.; Corsi, M.M.; Dozio, E. Natural zeolites chabazite/phillipsite/analcime increase blood levels of antioxidant enzymes. J. Clin. Biochem. Nutr. 2012, 50, 195-198. [CrossRef] [PubMed]

36. Superchi, P.; Saleri, R.; Ossiprandi, M.C.; Riccardi, E.; Passaglia, E.; Cavalli, V.; Beretti, V.; Sabbioni, A. Natural zeolite (chabazite/phillipsite) dietary supplementation influences faecal microbiota and oxidant status of working dogs. Ital. J. Anim. Sci. 2016, 16, 115-121. [CrossRef]

37. Ferreira, L.; Fonseca, A.M.; Botelho, G.; Aguiar, C.A.; Neves, I.C. Antimicrobial activity of faujasite zeolites doped with silver. Microporous Mesoporous Mater. 2012, 160, 126-132. [CrossRef]

38. Attanoos, R.L.; Churg, A.; Galateau-Salle, F.; Gibbs, A.R.; Roggli, V.L. Malignant Mesothelioma and Its Non-Asbestos Causes. Arch. Pathol. Lab. Med. 2018, 142, 753-760. [CrossRef] [PubMed]

39. Reinhart, K.O.; Nur Aainaa, H.; Haruna Ahmed, O.; Ab Majid, N.M. Effects of clinoptilolite zeolite on phosphorus dynamics and yield of Zea Mays L. cultivated on an acid soil. PLoS ONE 2018, 13, e0204401.

40. Sun, J.; Wu, Y.; Zhou, Y.; Lu, C.; Ahmad, H.; Zhang, H.; He, J.; Zhang, L.; Wang, T. Influence of Butyrate Loaded Clinoptilolite Dietary Supplementation on Growth Performance, Development of Intestine and Antioxidant Capacity in Broiler Chickens. PLOS ONE 2016, 11, e0154410.

41. Nizet, S.; Muñoz, E.; Fiebich, B.L.; Abuja, P.M.; Kashofer, K.; Zatloukal, K.; Tangermann, S.; Kenner, L.; Tschegg, C.; Nagl, D.; et al. Clinoptilolite in Dextran Sulphate Sodium-Induced Murine Colitis: Efficacy and Safety of a Microparticulate Preparation. Inflamm. Bowel Dis. 2018, 24, 54-66. [CrossRef]

42. Hossein Nia, B.; Khorram, S.; Rezazadeh, H.; Safaiyan, A.; Tarighat-Esfanjani, A. The Effects of Natural Clinoptilolite and Nano-Sized Clinoptilolite Supplementation on Glucose Levels and Oxidative Stress in Rats with Type 1 Diabetes. Can. J. Diabetes 2018, 42, 31-35. [CrossRef]

43. Potgieter, W.; Samuels, S.; Snyman, J.R. Potentiated clinoptilolite: Artificially enhanced aluminosilicate reduces symptoms associated with endoscopically negative gastroesophageal reflux disease and nonsteroidal anti-inflammatory drug induced gastritis. Clin. Exp. Gastroenterol. 2014, 7, 215-220.

44. Zarkovic, N.; Zarkovic, K.; Kralj, M.; Borovic, S.; Sabolovic, S.; Blazi, M.P.; Cipak, A.; Pavelic, K. Anticancer and antioxidative effects of micronized zeolite clinoptilolite. Anticancer. Res. 2003, 23, 1589-1595. [PubMed]

45. Montinaro, M.; Uberti, D.; Maccarinelli, G.; Bonini, S.A.; Ferrari-Toninelli, G.; Memo, M. Dietary zeolite supplementation reduces oxidative damage and plaque generation in the brain of an Alzheimer's disease mouse model. Life Sci. 2013, 92, 903-910. [CrossRef]

46. Andrić, L.; Trumić, M.; Trumić, M.; Nikolić, V. Micronization of zeolite in vibration mill. Reciklaza I Odrziv. Razvoj 2018, 11, 63-71. [CrossRef]

47. Beltcheva, M.; Metcheva, R.; Popov, N.; Teodorova, S.E.; Heredia-Rojas, J.A.; Rodríguez-de la Fuente, A.O.; Rodríguez-Flores, L.E.; Topashka-Ancheva, M. Modified Natural Clinoptilolite Detoxifies Small Mammal's Organism Loaded with Lead I. Lead Disposition and Kinetic Model for Lead Bioaccumulation. Biol. Trace Elem. Res. 2011, 147, 180-188. [CrossRef]

48. Nikpey, A.; Kazemian, H.; Safari-Varyani, A.; Rezaie, M.; Sirati-Sabet, M. Protective Effect of Microporous Natural Clinoptilolite on Lead-Induced Learning and Memory Impairment in Rats. Health Scope 2013, 2, 52-57. [CrossRef]

49. Papaioannou, D.; Katsoulos, P.D.; Panousis, N.; Karatzias, H. The role of natural and synthetic zeolites as feed additives on the prevention and/or the treatment of certain farm animal diseases: A review. Microporous Mesoporous Mater. 2005, 84, 161-170. [CrossRef] 
50. Kanyılmaz, M.; Tekelioğlu, N.; Sevgili, H.; Uysal, R.; Aksoy, A. Effects of dietary zeolite (clinoptilolite) levels on growth performance, feed utilization and waste excretions by gilthead sea bream juveniles (Sparus aurata). Anim. Feed Sci. Technol. 2015, 200, 66-75. [CrossRef]

51. Burmańczuk, A.; Markiewicz, W.; Burmańczuk, A.; Kowalski, C.; Roliński, Z.; Burmańczuk, N. Possibile use of natural zeolites in animal production and environment protection. J. Elem. 2015, 4, 803-811. [CrossRef]

52. Liu, R.; Lal, R. Nanoenhanced Materials for Reclamation of Mine Lands and Other Degraded Soils: A Review. J. Nanotechnol. 2012, 2012, 1-18. [CrossRef]

53. Katsoulos, P.D.; Karatzia, M.A.; Boscos, C.; Wolf, P.; Karatzias, H. In-field evaluation of clinoptilolite feeding efficacy on the reduction of milk aflatoxin M1 concentration in dairy cattle. J. Anim. Sci. Technol. 2016, 58, 24. [CrossRef]

54. Katsoulos, P.D.; Karatzia, M.A.; Polizopoulou, Z.; Florou-Paneri, P.; Karatzias, H. Effects of prolonged consumption of water with elevated nitrate levels on certain metabolic parameters of dairy cattle and use of clinoptilolite for their amelioration. Environ. Sci. Pollut. Res. 2015, 22, 9119-9126. [CrossRef] [PubMed]

55. Goff, J.P. Invited review: Mineral absorption mechanisms, mineral interactions that affect acid-base and antioxidant status, and diet considerations to improve mineral status. J. Dairy Sci. 2018, 101, 2763-2813. [CrossRef]

56. Schneider, A.F.; Zimmermann, O.F.; Gewehr, C.E. Zeolites in poultry and swine production. Cienc. Rural 2017, 47, e20160344. [CrossRef]

57. Nahm, K.H. Efficient feed nutrient utilization to reduce pollutants in poultry and swine manure. Crit. Rev. Environ. Sci. Technol. 2002, 32, 1-16. [CrossRef]

58. Fotidis, I.A.; Kougias, P.G.; Zaganas, I.D.; Kotsopoulos, T.A.; Martzopoulos, G.G. Inoculum and zeolite synergistic effect on anaerobic digestion of poultry manure. Environ. Technol. 2014, 35, 1219-1225. [CrossRef]

59. Walker, V. Ammonia Metabolism and Hyperammonemic Disorders. Adv. Clin. Chem. 2014, 67, 73-150. [PubMed]

60. Genuis, S.J.; Birkholz, D.; Ralitsch, M.; Thibault, N. Human detoxification of perfluorinated compounds. Public Health 2010, 124, 367-375. [CrossRef]

61. Bischoff, S.C.; Barbara, G.; Buurman, W.; Ockhuizen, T.; Schulzke, J.-D.; Serino, M.; Tilg, H.; Watson, A.; Wells, J.M. Intestinal permeability-A new target for disease prevention and therapy. BMC Gastroenterol. 2014, 14, 189. [CrossRef]

62. Colella, C. A critical reconsideration of biomedical and veterinary applications ofnatural zeolites. Clay Miner. 2018, 46, 295-309. [CrossRef]

63. McGhee, J.R.; Fujihashi, K. Inside the Mucosal Immune System. PLoS Biol. 2012, 10, e1001397. [CrossRef]

64. Ivkovic, S.; Deutsch, U.; Silberbach, A.; Walraph, E.; Mannel, M. Dietary supplementation with the tribomechanically activated zeolite clinoptilolite in immunodeficiency: Effects on the immune system. Adv. Ther. 2004, 21, 135-147. [CrossRef] [PubMed]

65. Bermudez-Brito, M.; Plaza-Díaz, J.; Muñoz-Quezada, S.; Gómez-Llorente, C.; Gil, A. Probiotic Mechanisms of Action. Ann. Nutr. Metab. 2012, 61, 160-174. [CrossRef] [PubMed]

66. Hemarajata, P.; Versalovic, J. Effects of probiotics on gut microbiota: Mechanisms of intestinal immunomodulation and neuromodulation. Ther. Adv. Gastroenterol. 2012, 6, 39-51. [CrossRef]

67. Sabbioni, A.; Ferrario, C.; Milani, C.; Mancabelli, L.; Riccardi, E.; di Ianni, F.; Beretti, V.; Superchi, P.; Ossiprandi, M.C. Modulation of the Bifidobacterial Communities of the Dog Microbiota by Zeolite. Front. Microbiol. 2016, 7, 1491. [CrossRef] [PubMed]

68. Zhu, C.; Grandhi, R.; Patterson, T.; Nicholson, S. A Review of Traumatic Brain Injury and the Gut Microbiome: Insights into Novel Mechanisms of Secondary Brain Injury and Promising Targets for Neuroprotection. Brain Sci. 2018, 8, 113. [CrossRef] [PubMed]

69. Belkaid, Y.; Hand, T.W. Role of the Microbiota in Immunity and Inflammation. Cell 2014, 157, $121-141$. [CrossRef] [PubMed]

70. Levy, R.; Rotfogel, Z.; Hillman, D.; Popugailo, A.; Arad, G.; Supper, E.; Osman, F.; Kaempfer, R. Superantigens hyperinduce inflammatory cytokines by enhancing the B7-2/CD28 costimulatory receptor interaction. Proc. Natl. Acad. Sci. USA 2016, 113, E6437-E6446. [CrossRef]

71. Actor, J.K. Role of Major Histocompatibility Complex in the Immune Response. In Elsevier's Integrated Review Immunology and Microbiology, 2nd ed.; Actor, J.K., Ed.; Elsevier: Philadelphia, PA, USA, 2012; Volume 5, pp. 33-41. 
72. He, L.; He, T.; Farrar, S.; Ji, L.; Liu, T.; Ma, X. Antioxidants Maintain Cellular Redox Homeostasis by Elimination of Reactive Oxygen Species. Cell. Physiol. Biochem. 2017, 44, 532-553. [CrossRef] [PubMed]

73. Pizzino, G.; Irrera, N.; Cucinotta, M.; Pallio, G.; Mannino, F.; Arcoraci, V.; Squadrito, F.; Altavilla, D.; Bitto, A. Oxidative Stress: Harms and Benefits for Human Health. Oxid. Med. Cell. Longev. 2017, 2017, 1-13. [CrossRef]

74. Araújo, R.F.F.D.; Martins, D.B.G.; Borba, M.A.C.S.M. Oxidative Stress and Disease. In The Transcription Factor Nrf2; Morales-Gonzales, J.A., Ed.; IntechOpen: London, UK, 2016; Volume 10, pp. 185-199.

75. Saribeyoglu, K.; Aytac, E.; Pekmezci, S.; Saygili, S.; Uzun, H.; Ozbay, G.; Aydin, S.; Seymen, H.O. Effects of clinoptilolite treatment on oxidative stress after partial hepatectomy in rats. Asian J. Surg. 2011, 34, $153-157$. [CrossRef]

76. Cai, Q.; Turner, B.D.; Sheng, D.; Sloan, S. The kinetics of fluoride sorption by zeolite: Effects of cadmium, barium and manganese. J. Contam. Hydrol. 2015, 177, 136-147. [CrossRef] [PubMed]

77. Bintaş, E.; Bozkurt, M.; Küçükyılmaz, K.; Konak, R.; Çınar, M.; Akşit, H.; Seyrek, K.; Çatlı, A.U. Efficacy of Supplemental Natural Zeolite in Broiler Chickens Subjected to Dietary Calcium Deficiency. Ital. J. Anim. Sci. 2014, 13, 275-283. [CrossRef]

78. Rana, C.; Mediha, H.A.; Naceur, M.H. Effects of the Incorporation of Zeolite on Zoo technical Parameters of Chicken. J. Anim. Sci. Livest. Prod. 2018, 2, 011. [CrossRef]

79. Shariatmadari, F. The application of zeolite in poultry production. World's Poult. Sci. J. 2008, 64, 76-84. [CrossRef]

80. Abraha, I.; Rimland, J.M.; Trotta, F.M.; Dell'Aquila, G.; Cruz-Jentoft, A.; Petrovic, M.; Gudmundsson, A.; Soiza, R.; O'Mahony, D.; Guaita, A.; et al. Systematic review of systematic reviews of non-pharmacological interventions to treat behavioural disturbances in older patients with dementia. The SENATOR-OnTop series. BMJ Open 2017, 7, e012759. [CrossRef] [PubMed]

81. Hecht, K. Biological rhythms and sleep rhythms. Aerosp. Environ. Med. 2007, 41, 59-64.

82. Mück-Šeler, D.; Pivac, N. The effect of natural clinoptilolite on the serotonergic receptors in the brain of mice with mammary carcinoma. Life Sci. 2003, 73, 2059-2069. [CrossRef]

83. Golokhvast, K.; Sergievich, A.; Grigoriev, N. Geophagy (rock eating), experimental stress and cognitive idiosyncrasy. Asian Pac. J. Trop. Biomed. 2014, 4, 362-366. [CrossRef]

84. Delavarian, M.; Hassanvand, A.; Gharibzadeh, S. Increasing performance in children with ADHD by trapping lead with a nano-zeolite. J. Neuropsychiatry Clin. Neurosci. 2013, 25, E23. [CrossRef]

85. Delavarian, M.; Hassanvand, A.; Gharibzadeh, S. Using natural zeolite as a transporter of dopamine. J. Neuropsychiatry Clin. Neurosci. 2013, 25, E21. [CrossRef]

86. Hassanvand, A.; Gharibzadeh, S. Is it possible to treat some brain diseases by drug-substituted zeolites? J. Neuropsychiatry Clin. Neurosci. 2013, 25, E04. [CrossRef]

87. Hassanvand, A.; Hajihassani, M.; Abdi, M.; Gharibzadeh, S. Drug delivery using nano-pore zeolites and ultrasound. J. Neuropsychiatry Clin. Neurosci. 2013, 25, E20. [CrossRef] [PubMed]

88. Apostolova, L.G. Alzheimer Disease. Contin. Lifelong Learn. Neurol. 2016, 22, 419-434. [CrossRef] [PubMed]

89. Bonini, S.A.; Premoli, M.; Tambaro, S.; Kumar, A.; Maccarinelli, G.; Memo, M.; Mastinu, A. Cannabis sativa: A comprehensive ethnopharmacological review of a medicinal plant with a long history. J. Ethnopharmacol. 2018, 227, 300-315. [CrossRef]

90. Kumar, A.; Premoli, M.; Aria, F.; Bonini, S.A.; Maccarinelli, G.; Gianoncelli, A.; Memo, M.; Mastinu, A. Cannabimimetic plants: Are they new cannabinoidergic modulators? Planta 2019. [CrossRef] [PubMed]

91. Mastinu, A.; Premoli, M.; Ferrari-Toninelli, G.; Tambaro, S.; Maccarinelli, G.; Memo, M.; Bonini, S.A. Cannabinoids in health and disease: Pharmacological potential in metabolic syndrome and neuroinflammation. Horm. Mol. Biol. Clin. Investig. 2018, 36, 20180013. [CrossRef]

92. Premoli, M.; Aria, F.; Bonini, S.A.; Maccarinelli, G.; Gianoncelli, A.; Pina, S.D.; Tambaro, S.; Memo, M.; Mastinu, A. Cannabidiol: Recent advances and new insights for neuropsychiatric disorders treatment. Life Sci. 2019, 224, 120-127. [CrossRef] [PubMed]

93. Moos, W.H.; Faller, D.V.; Harpp, D.N.; Kanara, I.; Pernokas, J.; Powers, W.R.; Steliou, K. Microbiota and Neurological Disorders: A Gut Feeling. Biores. Open Access 2016, 5, 137-145. [CrossRef]

94. Giau, V.; Wu, S.; Jamerlan, A.; An, S.; Kim, S.; Hulme, J. Gut Microbiota and Their Neuroinflammatory Implications in Alzheimer's Disease. Nutrients 2018, 10, 1765. [CrossRef] 
95. Griffiths, J.A.; Mazmanian, S.K. Emerging evidence linking the gut microbiome to neurologic disorders. Genome Med. 2018, 10, 98. [CrossRef] [PubMed]

96. Wang, Y.; Wang, Z.; Wang, Y.; Li, F.; Jia, J.; Song, X.; Qin, S.; Wang, R.; Jin, F.; Kitazato, K.; et al. The Gut-Microglia Connection: Implications for Central Nervous System Diseases. Front. Immunol. $2018,9$. [CrossRef]

97. Alkasir, R.; Li, J.; Li, X.; Jin, M.; Zhu, B. Human gut microbiota: The links with dementia development. Protein Cell 2016, 8, 90-102. [CrossRef] [PubMed]

98. Hu, X.; Wang, T.; Jin, F. Alzheimer's disease and gut microbiota. Sci. China Life Sci. 2016, 59, 1006-1023. [CrossRef] [PubMed]

99. La Rosa, F.; Clerici, M.; Ratto, D.; Occhinegro, A.; Licito, A.; Romeo, M.; Iorio, C.; Rossi, P. The Gut-Brain Axis in Alzheimer's Disease and Omega-3. A Critical Overview of Clinical Trials. Nutrients 2018, 10, 1267. [CrossRef] [PubMed]

100. Berti, V.; Walters, M.; Sterling, J.; Quinn, C.G.; Logue, M.; Andrews, R.; Matthews, D.C.; Osorio, R.S.; Pupi, A.; Vallabhajosula, S.; et al. Mediterranean diet and 3-year Alzheimer brain biomarker changes in middle-aged adults. Neurology 2018, 90, e1789-e1798. [CrossRef] [PubMed]

(C) 2019 by the authors. Licensee MDPI, Basel, Switzerland. This article is an open access article distributed under the terms and conditions of the Creative Commons Attribution (CC BY) license (http://creativecommons.org/licenses/by/4.0/). 